\title{
Readmissions due to traffic accidents at a general hospital ${ }^{\mathbf{1}}$
}

\author{
Luciana Paiva² \\ Damiana Aparecida Trindade Monteiro ${ }^{3}$ \\ Daniele Alcalá Pompeo ${ }^{4}$ \\ Márcia Aparecida Ciol ${ }^{5}$ \\ Rosana Aparecida Spadotti Dantas ${ }^{6}$ \\ Lídia Aparecida Rossi ${ }^{7}$
}

Objective: to verify the occurrence and the causes of hospital readmissions within a year after discharge from hospitalizations due to traffic accidents. Methods: victims of multiple traumas due to traffic accidents were included, who were admitted to an Intensive Care Unit. Sociodemographic data, accident circumstances, body regions affected and cause of readmission were collected from the patient histories. Results: among the 109 victims of traffic accidents, the majority were young and adult men. Most hospitalizations due to accidents involved motorcycle drivers (56.9\%). The causes of the return to the hospital were: need to continue the surgical treatment $(63.2 \%)$, surgical site infection $(26.3 \%)$ and fall related to the physical sequelae of the trauma (10.5\%). The rehospitalization rate corresponded to $174 / 1,000$ people/year. Conclusion: the hospital readmission rate in the study population is similar to the rates found in other studies. Victims of severe limb traumas need multiple surgical procedures, lengthier hospitalizations and extended rehabilitation.

Descriptors: Patient Admission; Patient Readmission; Accidents, Traffic.

\footnotetext{
${ }^{1}$ Paper extracted from doctoral dissertation "Quality of life related to health and return to work for victims of traffic accidents", presented to Escola de Enfermagem de Ribeirão Preto, Universidade de São Paulo, PAHO/WHO Collaborating Centre for Nursing Research Development, Ribeirão Preto, SP, Brazil.

2 PhD, RN, Hospital de Clínicas, Universidade Federal do Triângulo Mineiro, Uberaba, MG, Brazil.

3 Undergraduate student in Nursing, Escola de Enfermagem, Universidade Federal do Triangulo Mineiro, Uberaba, MG, Brazil.

${ }^{4}$ PhD, Assistant Professor, Departamento de Enfermagem Especializada, Faculdade de Medicina de São José do Rio Preto, São José do Rio Preto, SP, Brazil.

${ }^{5} \mathrm{PhD}$, Associate Professor, School of Medicine, University of Washington, Seattle, WA, United States.

${ }^{6}$ PhD, Associate Professor, Escola de Enfermagem de Ribeirão Preto, Universidade de São Paulo, PAHO/WHO Collaborating Centre for Nursing Research Development, Ribeirão Preto, SP, Brazil.

7 PhD, Full Professor, Escola de Enfermagem de Ribeirão Preto, Universidade de São Paulo, PAHO/WHO Collaborating Centre for Nursing Research Development, Ribeirão Preto, SP, Brazil.
}

Corresponding Author:

Luciana Paiva

Rua Dr. Hildebrando Pontes, 100, Apto. 102

Bairro: Mercês

CEP: 38060-250, Uberaba, MG, Brasil

E-mail: luciana.paiva@hotmail.com
Copyright @ 2015 Revista Latino-Americana de Enfermagem This is an Open Access article distributed under the terms of the Creative Commons Attribution Non-Commercial License (CC BY-NC).

This license lets others distribute, remix, tweak, and build upon your work non-commercially, and although their new works must also acknowledge you and be non-commercial, they don't have to license their derivative works on the same terms. 


\section{Introduction}

The traffic accidents, the second cause of general mortality in Brazil(1), constitute an important cause of trauma in the global population. The increase in these accidents is directly related to the industrial development of the $20^{\text {th }}$ century, the increase of the motor vehicle fleet, the high frequency of inappropriate behaviors and insufficient alertness of the drivers( ${ }^{(2)}$.

Trauma sequelae differ substantially for each person, as the victims of traffic accidents can injure different body regions. This situation overburdens the health system in all care sectors, ranging from emergency care to high-complexity services, as extended and high-cost hospitalizations influence the patients' rehabilitation and interfere in the victims' quality of life.

In Brazil, to minimize these impacts, the Ministry of health recommends access to rehabilitation for trauma victims with temporary or permanent physical, auditory, intellectual or visual sequelae. This rehabilitation is based on the promotion of the care needed to improve the patients' functions; through prevention measures, reduction of the rhythm of functional loss, recovery or compensation of the function $\operatorname{lost}^{(3)}$.

The change in the population's sociodemographic and epidemiological profile and the incorporation of new technologies in the care process support the need for health care assessment studies, through indicators that assess the results of the care process(4). Among the health indicators, the hospital readmission rate assesses the health service's performance, based on the longterm monitoring of the same hospital(5).

Hospital readmissions are defined as the admission of the patient to the same health service twice or more within one period after the discharge ${ }^{(6)}$. Different factors can be associated with rehospitalizations: inappropriate health care, improper rehabilitation procedures, early discharge, low treatment compliance by the patient, age and chronic illnesses ${ }^{(5)}$. Other factors not related to the quality of care can interfere in the readmissions, such as the proximity of the hospital, availability of beds and access regulation mechanisms ${ }^{(7)}$.

Early readmissions occur within 30 days after the hospitalization and can be associated with early discharge and hospital care quality problems ${ }^{(8)}$. Longer time intervals between hospital discharge and readmission are frequently associated with chronic illnesses, socioeconomic conditions and limited access to outpatient care ${ }^{(9)}$. In Brazil, studies are available that assessed the readmissions in specific populations, such as elderly and people discharged from intensive care. No studies have been found that were focused on readmissions due to traffic accidents.

The objective in this study was to characterize the victims of traffic accidents admitted to an Intensive Care Unit of a hospital in the interior of the State of Minas Gerais and to verify the occurrence of hospital readmissions related to the trauma within one year after the discharge from hospital.

\section{Method}

Approval for the study was obtained from the Institutional Review Board at Universidade Federal do Triângulo Mineiro, under protocol 1606. To develop the study, the standards for research established in National Health Council Resolution 196/96 were followed. The consent terms had been obtained in an earlier phase of the same study.

This observational, retrospective study was developed without finding with multiple trauma victims due to traffic accidents, hospitalized at the Intensive Care Unit (ICU) of a university hospital in the region Triângulo Mineiro. The hospital is a large public institution that attends to 27 cities in the macroregion Triângulo Sul, with 281 active beds in total and an estimated care population of 645 thousand people. The criteria to include the participants were: multiple trauma victims due to traffic accident, admitted to the ICU of a university hospital in the Triângulo Mineiro, between January 2008 and July 2010, independently of sex and aged 18 years or older. Patients who died during the first hospitalization were excluded.

To select the participants, a search was undertaken in the admission and discharge records of the ICU. This search permitted the identification of individuals admitted with a diagnosis of trauma due to traffic accidents, sociodemographic data and hospital registration number. After obtaining the information, the respective patient histories were accessed in the Medical Filing Service (SAME) to survey the hospitalization data. After the discharge, a new research was undertaken in the hospital system, looking for patients readmitted within one year after the discharge. After identifying these patients, new searches were undertaken in the files with emphasis on the causes of readmission.

The following variables were collected for the study: sociodemographic information (age, sex and 
origin); information related to the accident (weekday of occurrence and accident circumstances); body regions affected; and procedures related to the treatment after the accident (surgeries done, interval between other readmissions and their causes). To assess the severity of the trauma victims' injuries, the New Injury Severity Score (NISS) was used. Constructed based on the Abbreviated Injury Scale (AIS), this tool assesses the severity of the worst three injuries, independently of the affected body region. The score on this scale ranges between 1 and 75 and patients with an NISS score over 15 are considered as moderate and severe traumas.

All patients admitted between January 2008 and July 2010 were included in the study. The sample, considered representative of the population, was delimited by the period to collect data, which was based on the human resources and time available to conduct the study. The data were analyzed using absolute and relative frequencies, central trend and dispersion measures. To calculate the readmission rate, the time for readmission was limited to one year after the first discharge.

\section{Results}

In the study period, 137 victims of traffic accidents were admitted to the ICU. Twenty-eight patients were excluded, who died during the first hospitalization. The remaining 109 patients complied with the inclusion criteria. These victims' mean age was 37.1 years [Standard Error $(\mathrm{SE})=14.3$ ], ranging from 18 to 75 years, with a predominance of male victims (69.7\%).

The traffic accidents were distributed among all weekdays, with a higher concentration at weekends ( $41.3 \%$ on Saturdays and Sundays) and at night (51.4\%) (Figure 1).

The highest proportion of traffic accident victims referred to motorcycle drivers (56.9\%), followed by car passengers $(31.2 \%)$. The smallest percentages of victims were passengers of heavy vehicles, trucks and buses $(5.5 \%)$, followed by cyclists $(6.4 \%)$.

All patients were severe trauma victims with NISS scores ranging between 41 and 75 points. Table 1 shows the distribution of the affected body region according to the type of vehicle. A large number of victims had associated injuries, such as fractures and traumatic brain injuries. In the motorcycle accident victims, the most affected body regions were the limbs (46.8\%) and skull $(24.2 \%)$. In the accidents involving cars, $70.6 \%$ of the victims presented skull (42.9\%), face (28.6\%) and limb $(28.6 \%)$ traumas. Victims of accidents involving heavy vehicles (truck/bus) had greater proportions of skull (33.3\%) and limb (33.3\%) injuries. These two groups showed a smaller number of events ( 7 and 6 , respectively).

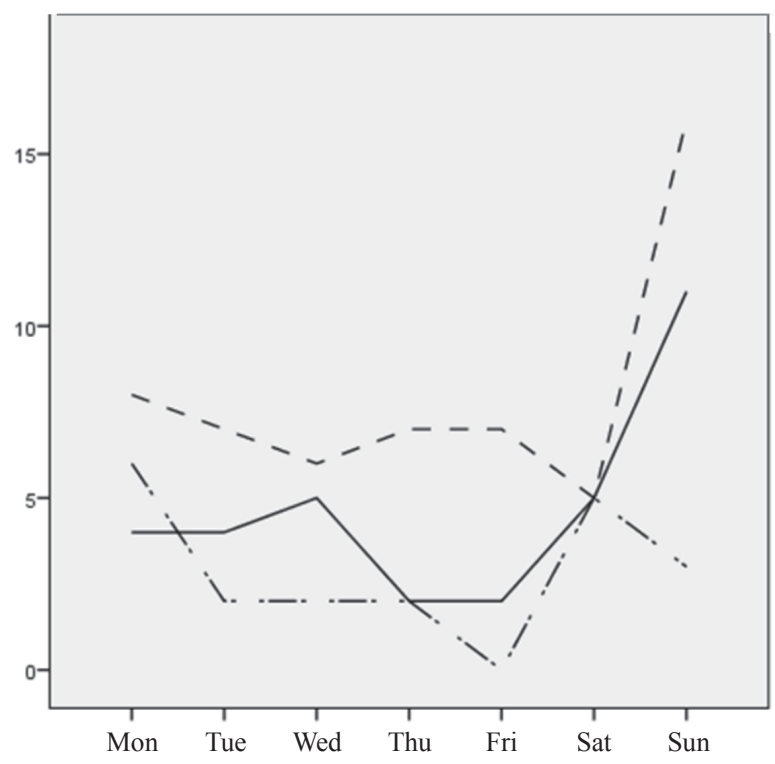

Day of the week in which the accident occurred

Figure 1- Temporal distribution of traffic accidents according to shift in which the accident occurred and weekdays. Uberaba, MG, Brazil, January 2008 till July 2010

The mean number of days during the first hospitalization was 35 days ( $\mathrm{SE}=31.1$ ), ranging from 2 to 155 days, while the mean length of hospitalization at the Intensive Care Unit was 14 days $(\mathrm{SE}=13)$, ranging from 1 to 87 days.

Among the 109 patients, 19 (17.4\%) needed readmission rate corresponding to $174 / 1,000$ persons/ year. When comparing individuals who needed readmission with victims who were not readmitted, a predominance of male individuals, motorcycle accidents and lower limb injuries is observed in the two groups (Table 2).

The return period to the hospital ranged between 6 and 332 days, and the mean length between discharge and return was 163 days $(S E=13)$. The causes of the return to hospital were: need to continue the surgical treatment $(63.2 \%)$, surgical site infection $(26.3 \%)$ and fall $(10.5 \%)$ related to the physical sequelae of the trauma, responsible for a readmission. 
Table 1 - Distribution of the affected body region according to the type of vehicle in the accident. Uberaba, MG, Brazil, January 2008 till July 2010

\begin{tabular}{lcccc}
\hline Affected body region & $\begin{array}{c}\text { Motorcycle } \\
\mathbf{n}=\mathbf{6 2}\end{array}$ & $\begin{array}{c}\text { Car } \\
\mathbf{n}=\mathbf{3 4}\end{array}$ & $\begin{array}{c}\text { Bicycle } \\
\mathbf{n}=\mathbf{7}\end{array}$ & $\begin{array}{c}\text { Truck/Bus } \\
\mathbf{n}=\mathbf{6}\end{array}$ \\
\hline Limbs \% $(\mathrm{n})$ & $46.8(29)$ & $70.6(24)$ & $28.6(2)$ & $33.3(2)$ \\
Skull \% $(\mathrm{n})$ & $24.2(15)$ & $32.4(11)$ & $42.9(3)$ & $33.3(2)$ \\
Abdomen \% $(\mathrm{n})$ & $19.4(12)$ & $26.5(9)$ & $0(0)$ & $16.7(1)$ \\
Chest \% $(\mathrm{n})$ & $9.7(6)$ & $14.7(5)$ & $0(0)$ & $16.7(1)$ \\
Spine \% $(\mathrm{n})$ & $6.5(4)$ & $5.9(2)$ & $14.3(1)$ & $16.7(1)$ \\
Face \% $(\mathrm{n})$ & $3.2(2)$ & $2.9(1)$ & $28.6(2)$ & $16.7(1)$ \\
\hline
\end{tabular}

Table 2 - Characterization of traffic accident victims according to readmission within one year after the discharge. Uberaba, MG, Brazil, January 2008 till July 2010

\begin{tabular}{|c|c|c|}
\hline Characteristic & $\begin{array}{l}\text { Group without readmission } \\
(n=90)\end{array}$ & $\begin{array}{l}\text { Group with readmission } \\
(n=19)\end{array}$ \\
\hline Sex, \% male (n) & $71.1(64)$ & $63.2(12)$ \\
\hline \multicolumn{3}{|c|}{ Trauma mechanism, \% in each category $(n)$} \\
\hline Motorcycle & $56.7(51)$ & $57.9(11)$ \\
\hline Car & $34(37.8)$ & $31.5(6)$ \\
\hline Cyclist & $5.6(5)$ & $10.6(2)$ \\
\hline \multicolumn{3}{|l|}{ Affected body region $\%(n)^{*}$} \\
\hline Limbs & $47.8(43)$ & $52.6(10)$ \\
\hline Skull & $27.8(25)$ & $31.6(6)$ \\
\hline Abdomen & $20(18)$ & $21.1(4)$ \\
\hline Spine & $5.6(5)$ & $15.8(3)$ \\
\hline Chest & $11.1(10)$ & $10.5(2)$ \\
\hline Face & $5.6(5)$ & $5.3(1)$ \\
\hline \multicolumn{3}{|c|}{ Time between discharge and readmission, \% in each category ( $\mathrm{n}$ ) } \\
\hline $0-14$ days & ---- & $26.3(5)$ \\
\hline $15-30$ days & ---- & $42.1(8)$ \\
\hline $31-60$ days & ---- & $31.6(6)$ \\
\hline \multicolumn{3}{|c|}{ Causes of readmission, $\%$ in each category ( $n$ ) } \\
\hline Continuity of surgical treatment & ---- & $63.2(12)$ \\
\hline Surgical site infection & ---- & $26.3(5)$ \\
\hline Fall & ---- & $10.5(2)$ \\
\hline
\end{tabular}

* The same patient can present trauma in more than one body area

\section{Discussion}

The consequences of traffic accidents can range from lesser sequelae to deaths or physical disabilities, which overburden the health system, with extended and expensive hospitalizations; followed by long-term rehabilitation programs(10). In this study, most victims were young and adult men, similar to other studies in Brazil(11). The impact and economic losses for this population segment can be strong, including potential years of life lost, periods of absence from work, early retirements, physical, emotional and moral limitations of the victim and negative impact on the family and social structure the victim is inserted in ${ }^{(11)}$.
The traffic accident sequelae determine important morbidity and mortality in the victims and put a great economic strain on the country, in the treatment and the loss of an important part of the income-generating population, due to deaths and sequelae ${ }^{(12)}$.

In this study, like in others found in the literature, traffic accident records are higher at weekends ${ }^{(1)}$ and distributed uniformly during the other weekdays. The enhanced number of accidents at weekends can be associated with alcohol intake and the use of other drugs $^{(12)}$. Research reports that most accidents happen at night and can be explained by fatigue at the end of the day and the great flow of vehicles at rush hours ${ }^{(13-14)}$. The high level of severity at night is due to factors like 
visibility, excessive speed, disrespect for traffic signs, alcohol intake and drug use ${ }^{(13)}$. In addition, the long and uninterrupted work journeys should be considered an important factor associated with the higher occurrence of accidents at night ${ }^{(14)}$.

The most common vehicle in accidents was the motorcycle (56.9\%). In recent years, an increase was observed in the risk of death due to accidents involving motorcycles ${ }^{(15)}$, mainly in large Brazilian cities and, when compared to car accidents in emergency care, this increase is significant ${ }^{(15)}$. The growth of the motorcycle fleet all over the country occurred due to the greater acceptance of this type of vehicle in the general population and its use for speed delivery of products and articles, favoring the cost-benefit relation when compared to other motor vehicles ${ }^{(16)}$.

In general, it can be affirmed that limb injuries and traumatic brain injuries stood out among the most severe injuries when compared to other body regions. The distribution patterns of the injuries can be due to the type of accident the motorcycle victims were victims of, with frequent limb injuries ${ }^{(17)}$.

In this study, the length of hospitalization ranged between 2 and 155 days, similar to the findings in the literature(18). The nature of the lesions can influence the length of the patients' hospitalization, type of treatment and conditions upon discharge. Hospitalization at an intensive care unit occurred for all study participants, with a mean length of 14 days. The relation between the longer ICU hospitalization, severity and incidence of complications after the trauma is discussed in the literature ${ }^{(19)}$.

The results related to readmissions after the trauma in the study population support the findings from other studies involving severe limb trauma victims, who need multiple surgical procedures, extended hospitalization and rehabilitation. In a study developed to analyze hospitalizations of all patients over 18 years of age, most patients returned to the hospital within 30 days $^{(4)}$.

In this study, surgical site infection was the cause of readmission for $26.3 \%$ of the patients. The most frequent intra-hospital complications in the orthopedic trauma victims are surgical wound infection with the need for a new surgical approach and osteomyelitis(20). The presence of these complications represents a severe condition that influences the morbidity and mortality of the patients who stay. Other studies have already reported that orthopedic trauma patients submitted to surgeries present high rates of surgical site infection and that this situation is related to the severity and complexity of the injuries, the number of surgeries on the injury site and clinical risk factors like preexisting diseases $^{(21)}$. These infections are severe complications for the patients, the multiprofessional team and hospital institutions. They extend the length of the hospitalization, double the readmission rates and increase care costs by more than $300 \%$. In addition, they cause important physical limitations, which significantly reduce the operated patients' quality of life(22). The incidence of trauma-related orthopedic infections can range between $4.2 \%{ }^{(22)}$ and $22.7 \%(22)$.

Another relevant aspect are the temporary and permanent disabilities after traffic accidents, which contribute to increase the readmission rate and reduce the functional ability, muscle strength, postural instability and higher fall rates of the victims, which have been assessed in studies on these people's rehabilitation ${ }^{(23)}$.

The role of the multiprofessional and mainly the nursing team is highlighted in planning for discharge, as a fundamental tool for comprehensive care during the hospitalization and after discharge. Health education is an important strategy to direct the care needed, to be delivered to the patient at home, with a view to avoiding readmissions and facilitating the early identification of signs of complications after the discharge, promoting improvements in the users' health. This study is limited by the sample size and the length of the monitoring, established in function of the time available to conduct the study.

\section{Conclusions}

After the discharge, most readmissions happened more than 30 days after the discharged and were related to victims of motorcycle accidents who suffered orthopedic traumas. Most hospital readmissions in this study were planned, due to the need to continue the therapeutic assessment.

The readmission rate can be an important indicator of care quality focused on traffic accident victims and their costs. Further research is needed to focus on these aspects. 


\section{References}

1. Silva MAI, Pan R, Melo L, Bortoli PS, Nascimento LC. Perfil dos atendimentos a crianças e adolescentes vítimas de causas externas de morbimortalidade, 20002006. Rev Gaúcha Enferm. 2010;31(2):351-8.

2. Bastos YGL, Andrade SM, Soares DA. Características dos acidentes de trânsito e das vítimas atendidas em serviço pré-hospitalar em cidade do Sul do Brasil, 1997/2000. Cad Saúde Pública. 2005;21(3):815-22.

3. Ministério da Saúde (BR). Consulta Pública no 17, de 29 de Agosto de 2012. Minuta de Portaria que aprova, na forma do anexo, o texto da "Linha de Cuidado ao Trauma". Diário Oficial [da] República Federativa do Brasil [Internet]. Brasília: Ministério da Saúde; 2012 [acesso 29 ago 2013]. p. 50. Disponível em: http:// www.cro-ce.org.br/pdf/consulta-publica.pdf.

4. Maurer PP, Ballmer PE. Hospital readmissions are predictable and avoidable? Swiss Mid Wkly. 2004;134(41-42):606-11.

5. Clarke A, Rao M. Developing quality indicators to assess quality of care. Qual Saf Health Care. 2004;13(4):248-9.

6. Moreira ML, DutilhNovaes HM. Internações no sistema de serviços hospitalares, SUS e não SUS: Brasil, 2006. Rev Bras Epidemiol. 2011;14(3):411-22.

7. Heggestada T. Do Hospital length of stay and staffing ratio affect elderly patients risk of readmission? A nation-wide study of Norwegian hospitals. Health Serv Res. 2002;37(3):647-65.

8. Japiassú AM, Cukier MS, Queiroz AGCM, Gondim CRN, Penna GLA, Almeida GF, et al. Fatores preditores precoces de reinternação em unidade de terapia intensiva. Rev Bras Ter Intensiva. 2009;21(4):353-8.

9. Castro MSM, Carvalho MS, Travassos C. Factors associated with readmission to a general hospital in Brazil. Cad Saúde Pública. 2005;21(4):1186-2000.

10. Debieux P, Chertman C, Mansur NSB, Dobashi E, Fernandes HJA. Lesões do aparelho locomotor nos acidentes com motocicleta. Acta Ortop Bras. 2010;18(6): 353-6. D

11. Abreu AMM, Jomar RT, Thomaz RGF, Guimarães RM, Lima JMB, Figueirò RFS. Impacto da lei seca na mortalidade por acidentes de trânsito. Rev Enferm UERJ. $2012 ; 20(1): 21-6$.
12. Ferreira TFA, Nápolis ACR, Lima CS, Araújo LC, Garcia CB, Lima OS, et al. Estudo da gravidade das pacientes vítimas de acidentes de trânsito atendidos pelo hospital de clínicas de Uberlândia de dezembro de 2005 a março de 2006 segundo índices de trauma. Biosci J. 2009;25(2):152-60.

13. Bastos YGL, Andrade SM, Soares DA. Características dos acidentes de trânsito e das vítimas atendidas em serviço pré-hospitalar em cidade do Sul do Brasil, 1997/2000. Cad Saúde Pública. 2005;21(3):815-22.

14. Silva DW, Andrade SM, Soares DA, Nunes EFPA, Melchior R. Condições de trabalho e riscos no trânsito urbano na ótica de trabalhadores motociclistas. Physis 2008;18(2):339-60.

15. Abreu AMM, Lima JMB, Griep RH. Acidentes de trânsito e a frequência dos exames de alcoolemia com vítimas fatais na cidade do Rio de Janeiro. Esc Anna Nery. 2009;13(1):44-50.

16. Bacchieri G, Barros AJD. Acidentes de trânsito no Brasil de 1998 a 2010: muitas mudanças e poucos resultados. Rev Saúde Pública. 2011;45(5):949-63.

17. Gawryszewski VP, Coelho HMM, Scarpelini S, Zan Renato JMHPM, Rodrigues EMS. Perfil dos atendimentos a acidentes de transporte terrestre por serviços de emergência em São Paulo, 2005. Rev Saúde Pública. 2009;43(2):275-82.

18. Andrade LM, Lima MA, Silva CHC, Caetano JA. Acidentes de motocicleta: características das vítimas e dos acidentes em hospital de Fortaleza - CE, Brasil. Rev Rene. 2009;10(4):52-9.

19. McKevitt EC, Calvert E, Ng A, Simons RK, Kirkpatrick AW, Appleton $L$, et al. Geriatric trauma: resource use and patient outcomes. Can J Surg. 2003;46(3):211-5.

20. Castro RRM, Ribeiro NF, Andrade AM, J BD. Perfil dos pacientes da enfermaria de ortopedia de um hospital público de Salvador-Bahia. Acta Ortop Bras. 2013;21(4):191-4.

21. Thu LT, Dibley MJ, Ewald B, Tien NP, Lam LD. Incidence of surgical site infections and accompanying risk factors in Vietnamese. Orthopaedic Patients. J Hosp Infect. 2005;60(4):360-7.

22. Maksimovic J, Markovic-Denic L, Bumbasirevic M, Marinkovic' J. Incidence of surgical site infections in the departments of orthopedics and traumatology. Vojnosanit Pregl. 2006;63(8):725-9. 
23. Souza JAG, Iglesias ACRG. Trauma no idoso. Rev

Assoc Med Bras. 2002;48(1):79-86.

Received: July $3^{\text {rd }} 2014$ 